\title{
Studies on the transformation of calcium sulphate dihydrate to hemihy- drate in the wet process phosphoric acid production
}

\author{
Barbara Grzmil", Bogumił Kic, Olga Żurek, Konrad Kubiak \\ West Pomeranian University of Technology, Szczecin, Institute of Chemical and Environment Engineering, ul. Pułaskiego 10, \\ 70-322 Szczecin, Poland \\ "Corresponding author: e-mail: barbara.grzmil@zut.edu.pl
}

\begin{abstract}
The influence of the process temperature from $85^{\circ} \mathrm{C}$ to $95^{\circ} \mathrm{C}$, the content of phosphates and sulphates in the wet process phosphoric acid (about 22-36 wt $\% \mathrm{P}_{2} \mathrm{O}_{5}$ and about 2-9 $\mathrm{wt} \% \mathrm{SO}_{4}^{2-}$ ) and the addition of $\alpha \mathrm{CaSO}_{4} \cdot 0.5 \mathrm{H}_{2} \mathrm{O}$ crystallization nuclei (from $10 \%$ to $50 \%$ in relation to $\mathrm{CaSO}_{4} \cdot 2 \mathrm{H}_{2} \mathrm{O}$ ) on the transformation of calcium sulphate dihydrate to hemihydrate has been determined. The wet process phosphoric acid and phosphogypsum from the industrial plant was utilized. They were produced by reacting sulphuric acid with phosphate rock (Tunisia) in the DH-process. The X-ray diffraction analysis was used to determine the phase composition and fractions of various forms of calcium sulphates in the samples and the degree of conversion of $\mathrm{CaSO}_{4} \cdot 2 \mathrm{H}_{2} \mathrm{O}$ to $\alpha \mathrm{CaSO}_{4} \cdot 0.5 \mathrm{H}_{2} \mathrm{O}$ and $\mathrm{CaSO}_{4}$. It was found that the transformation of $\mathrm{CaSO}_{4} \cdot 2 \mathrm{H}_{2} \mathrm{O}$ to $\alpha \mathrm{CaSO}_{4} \cdot 0.5 \mathrm{H}_{2} \mathrm{O}$ should be carried out in the presence of $\alpha \mathrm{CaSO}_{4} \cdot 0.5 \mathrm{H}_{2} \mathrm{O}$ crystallization nuclei as an additive (in the amount of $20 \%$ in relation to $\mathrm{CaSO}_{4} \cdot 2 \mathrm{H}_{2} \mathrm{O}$ ), at temperatures $90 \pm 2^{\circ} \mathrm{C}$, in the wet process phosphoric acid containing the sulphates and phosphates in the range of $4 \pm 1 \mathrm{wt} \%$ and $27 \pm 1 \mathrm{wt} \%$, respectively.
\end{abstract}

Keywords: wet process phosphoric acid; phosphogypsum; transformation; calcium hemihydrate.

\section{INTRODUCTION}

The world phosphoric acid production amounted to 39.8 million tons of $\mathrm{P}_{2} \mathrm{O}_{5}$ in 2009 , and, according to forecasts, will increase to 46.9 million tons of $\mathrm{P}_{2} \mathrm{O}_{5}$ by 2013 $\mathbf{1 , 2}$.The largest consumption of phosphoric acid in 2009 was in Asia (30\%), United States (22\%) and Southwest Asia $(10 \%){ }^{3}$. The phosphoric acid is produced by two commercial methods: wet process and thermal process. In the wet process the phosphate rock is extracted by acids (hydrochloric, nitric, sulphuric acids). The wet process phosphoric acid is utilized in $80-85 \%$ in the production of fertilizers, mainly triple superphosphate and ammonium phosphates ${ }^{1}$.

The wet process phosphoric acid can be obtained by the decomposition of phosphate rock with sulphuric acid by the following methods: dihydrate (DH-process), hemihydrate (HH-process) and by combined processes 4-15. The latter group includes various variants of process operation such as hemi-dihydrate transformation (HDH-process), di-hemihydrate transformation process (DHH-process) and hemi-di-hemihydrate transformation (HDHH-process). The primary objective of these processes was the achievement of high degree of phosphate rock conversion, a reduction of the phosphates content (phosphate losses) in waste $\mathrm{CaSO}_{4} \cdot \mathrm{nH}_{2} \mathrm{O}$, an enhancement of the degree of phosphates conversion from phosphate rock to the product, and the generation of waste with purity as high as possible ${ }^{4,5}$. The phosphates content in the calcium sulphate hydrate depends on the production method used. Their content results from the presence in this waste of unreacted phosphoric raw material, unwashed phosphoric acid and due to the cocrystallization of $\mathrm{CaHPO}_{4} \cdot 2 \mathrm{H}_{2} \mathrm{O}$ with $\mathrm{CaSO}_{4} \cdot \mathrm{nH}_{2} \mathrm{O}^{4,5}$.

In the wet process phosphoric acid production by the DH-process as much as 4-5 tons of phosphogypsum (PG) is generated per each ton $\mathrm{P}_{2} \mathrm{O}_{5}$ in the acid. Phosphogypsum is a waste by-product mainly disposed in landfills. Throughout the world in numerous landfills (some ac- tive, some closed, some lost or abandoned) located in 50 countries there are about 5 billion tons of PG and the annual production is estimated to be $100-200$ million tons ${ }^{16}$. For example, in China alone there are more than 200 million tons of PG in landfills and this quantity increases annually by 20 million tons. The phosphogypsum is characterized by the particles size in the range of 5-300 $\mu \mathrm{m}$, significant humidity $10-40 \mathrm{wt} \% \mathrm{H}_{2} \mathrm{O}$ and it contains various impurities, such as phosphates, silicates, alkali-earth metals, fluorides, toxic and radioactive elements ${ }^{\mathbf{4 , 5}}$. The actual content of these elements depends on the particular method of processing. With regard to above-mentioned physicochemical properties, the degree of utilization of the considerable quantities of phosphogypsum generated annually still remains below $15 \%{ }^{5,16}$. More than 50 different methods have been proposed for phosphogypsum utilization in agriculture (as a source of calcium and sulphur, soil conditioner, filler in the production of fertilizer), construction (as setting regulator in cement, plaster, plasterboard, gypsum blocks), road building, industrial (as filler/pigment, production of ammonium sulphate and sulphuric acid), other (mine leveling, land reclamation) ${ }^{16-19}$.

Only limited amounts of phosphogypsum are presently used for purposes such as building construction materials or road pavements. Currently in Europe, only PG produced by Prayon SA Company (DHH-process, Belgium) is used as plaster on a commercial scale (80\% of the total production). In Finland (Kemira GrowHow) some phosphogypsum is applied in the paper industry ${ }^{5,11}$.

The production of wet process phosphoric acid by $\mathrm{DH}-$ process is carried out within the crystallization region of metastable $\mathrm{CaSO}_{4} \cdot 2 \mathrm{H}_{2} \mathrm{O}$ whereas that carried out by $\mathrm{HH}$-process within the crystallization region of metastable $\alpha \mathrm{CaSO}_{4} \cdot 0.5 \mathrm{H}_{2} \mathrm{O}^{* 4,5,7,8,11,12,15}$. The crystallization regions of both calcium sulphate hydrates are separated by metastable equilibrium curve $\mathrm{CaSO}_{4} \cdot 2 \mathrm{H}_{2} \mathrm{O} \Leftrightarrow \mathrm{CaSO}_{4} \cdot 0.5 \mathrm{H}_{2} \mathrm{O}$. The location of this curve depends on the concentration 
of sulphates and various impurities in the liquid phase of the reaction mixture ${ }^{4,5,20-23}$. Along with an increase in the of $\mathrm{SO}_{4}{ }^{2-}$ concentration the equilibrium curve is shifted in the direction at lower temperatures and lower phosphate concentration. Therefore, the production of wet process phosphoric acid by dihydrate method at a higher concentration of sulphates should be carried out at lower temperatures. For the pure system containing 30 wt $\% \mathrm{P}_{2} \mathrm{O}_{5}$ and $5 \mathrm{wt} \% \mathrm{SO}_{4}{ }^{2-}$ the conversion temperature for $\mathrm{CaSO}_{4} \cdot 2 \mathrm{H}_{2} \mathrm{O} \Leftrightarrow \mathrm{CaSO}_{4} \cdot 0.5 \mathrm{H}_{2} \mathrm{O}^{*}$ is approximately $68^{\circ} \mathrm{C}$, whereas at $10 \mathrm{wt} \% \mathrm{SO}_{4}{ }^{2-}$ is only $56^{\circ} \mathrm{C}$. On the other hand, an increase in the sulphate concentration in the liquid phase of the reaction mixture affects the crystal habit of $\mathrm{CaSO}_{4} \cdot 2 \mathrm{H}_{2} \mathrm{O}$ formed and leads to lowering the decomposition degree of phosphate raw material to the caused by encapsulation of raw material particles by calcium sulphate hydrate ${ }^{1,5}$. Moreover the crystal habit influences on the efficiency of filtration and washing the precipitate as well as on losses of phosphate in the phosphogypsum due to incomplete washing of $\mathrm{H}_{3} \mathrm{PO}_{4}$.

According to Reference Document on Best Available Techniques for the Manufacture of Large Volume Inorganic Chemicals in Europe a wet process phosphoric acid should be obtained using the following techniques: modified DH-process, transformation processes (HDH and DHH processes) on existing installations ${ }^{5}$. However, the transformation process with double-stage filtration should be applied in new installations.

The DHH route involves the decomposition of phosphate material and crystallization of $\mathrm{CaSO}_{4} \cdot 2 \mathrm{H}_{2} \mathrm{O}$ at temperature of $80^{\circ} \mathrm{C}$, the separation of precipitate from wet process phosphoric acid $\left(32-38 \mathrm{wt} \% \mathrm{P}_{2} \mathrm{O}_{5}\right)$ on the filter, the transformation of calcium sulphate dihydrate to hemihydrate at temperature $100^{\circ} \mathrm{C}$ with enhanced content of sulphates $\left(10-20 \mathrm{wt} \% \mathrm{H}_{2} \mathrm{SO}_{4}, 20-30 \mathrm{wt} \%\right.$ $\mathrm{P}_{2} \mathrm{O}_{5}$ ), the separation of $\alpha \mathrm{CaSO}_{4} \cdot 0.5 \mathrm{H}_{2} \mathrm{O}^{*}$ precipitate on the filter followed by washing, and the phosphoric is recycled to the first stage of process. In this process a high $\mathrm{P}_{2} \mathrm{O}_{5}$ efficiency (98\%) is achieved and a relatively pure hemihydrate is obtained $\mathrm{d}^{\mathbf{4 , 5}}$. For comparison, the traditional DH-process gives lower $\mathrm{P}_{2} \mathrm{O}_{5}$ efficiency (94-96\%), lower phosphate content (26-32 wt\% $\mathrm{P}_{2} \mathrm{O}_{5}$ ) in the wet process phosphoric acid and impure calcium sulphate dihydrate containing $0.75 \mathrm{wt} \% \mathrm{P}_{2} \mathrm{O}_{5}, 5$.

The aim of the study was to investigate the possibilities to perform the transformation of calcium sulphate dihydrate to hemihydrate at temperature lower than $100^{\circ} \mathrm{C}$ and with a lower sulphate content $(<10 \mathrm{wt} \%$ $\mathrm{H}_{2} \mathrm{SO}_{4}$ ) in the wet process phosphoric acid. The influence of process temperature, the content of phosphates and sulphates in the wet process phosphoric acid and the presence of additives of $\alpha \mathrm{CaSO}_{4} \cdot 0.5 \mathrm{H}_{2} \mathrm{O}$ crystallization nuclei on the transformation of calcium sulphate dihydrate to hemihydrate has been determined.

\section{MATERIAL AND METHODS}

\section{Characteristics of utilized raw materials}

The wet process phosphoric acid and phosphogypsum from an industrial installation were used in the study. They were obtained as a result of phosphate rock (Tunisia) decomposition with sulphuric acid in DH-process
Table 1. The chemical composition of phosphate rock Tunisia and the products of decomposition of phosphorite by sulphuric acid

\begin{tabular}{|l|r|c|c|}
\hline \multirow{2}{*}{ Component } & $\begin{array}{c}\text { Tunisia } \\
\text { phosphorite }\end{array}$ & Unwashed PG & $\begin{array}{c}\text { Wet process } \\
\text { phosphoric } \\
\text { acid }\end{array}$ \\
\cline { 2 - 4 } & \multicolumn{3}{|c|}{ content (wt\%) } \\
\hline $\mathrm{H}_{2} \mathrm{O}$ & 1.97 & 35.72 & \\
\hline total $\mathrm{P}_{2} \mathrm{O}_{5}$ & 29.20 & 13.90 & 22.30 \\
\hline $\mathrm{SO}_{4}{ }^{2-}$ & 5.10 & 52.99 & 2.00 \\
\hline $\mathrm{CaO}$ & 49.70 & 30.92 & 0.12 \\
\hline $\mathrm{MgO}$ & 0.55 & 0.28 & 0.53 \\
\hline $\mathrm{Al}$ & 0.20 & 0.10 & 0.15 \\
\hline $\mathrm{Fe}$ & 0.19 & 0.09 & 0.17 \\
\hline $\mathrm{F}$ & 3.44 & 2.85 & 0.95 \\
\hline $\mathrm{SiO}_{2}$ & 3.10 & 2.18 & 0.44 \\
\hline
\end{tabular}

(Table 1). In order to increase the content of phosphates and sulphates in the wet process phosphoric acid both phosphoric acid $\left(61.5 \mathrm{wt} \% \mathrm{P}_{2} \mathrm{O}_{5}\right)$ and sulphuric acid (95 $\left.\mathrm{wt} \% \mathrm{SO}_{4}{ }^{2-}\right)$ of analytical grade were added.

The crystallization nuclei of calcium sulphate hemihydrate were prepared from washed phosphogypsum in the transformation process in phosphoric acid solution (26 wt $\% \mathrm{P}_{2} \mathrm{O}_{5}$ and $6.8 \mathrm{wt} \% \mathrm{SO}_{4}{ }^{2-}$ ) at $95^{\circ} \mathrm{C}$ for $2 \mathrm{~h}$ in a laboratory shaker with water bath (type 357 Elpinplus, 200 cycles/min, amplitude 5). The fraction of calcium sulphate phases in such obtained crystallization nuclei was the following: $96.2 \% \alpha \mathrm{CaSO}_{4} \cdot 0.5 \mathrm{H}_{2} \mathrm{O}, 0.3 \% \mathrm{CaSO}_{4} \cdot 2 \mathrm{H}_{2} \mathrm{O}$, and $3.5 \% \mathrm{CaSO}_{4}$.

\section{Sample preparation procedure}

The transformation of calcium sulphate dihydrate to hemihydrate in the wet process phosphoric acid was carried out at the mass ratio of the liquid phase to the solid phase of $3: 1$. The transformation temperature was varied in the range from $85^{\circ} \mathrm{C}$ to $95^{\circ} \mathrm{C}$. The content of phosphates and sulphates in the phosphoric acid was changed from about $22 \mathrm{wt} \% \mathrm{P}_{2} \mathrm{O}_{5}$ to $36 \mathrm{wt} \% \mathrm{P}_{2} \mathrm{O}_{5}$ and from about $2 \mathrm{wt} \% \mathrm{SO}_{4}{ }^{2-}$ to $9 \mathrm{wt} \% \mathrm{SO}_{4}{ }^{2-}$, respectively. The addition of $\alpha \mathrm{CaSO}_{4} \cdot 0.5 \mathrm{H}_{2} \mathrm{O}$ crystallization nuclei was varied from $10 \%$ to $50 \%$ (in relation to $\mathrm{CaSO}_{4} \cdot 2 \mathrm{H}_{2} \mathrm{O}$ ). The nuclei were added to a phosphogypsum suspension in the phosphoric acid at the process temperature.

The transformation was carried out in a tightly closed Erlenmeyer flask placed in a laboratory shaker with water bath (type 357 Elpinplus, 200 cycles/min, amplitude 5). The transformation of calcium sulphate dihydrate was carried out for $2 \mathrm{~h}$ or $1.5 \mathrm{~h}$. After completing the process the wet process phosphoric acid was separated from calcium sulphate hydrate. The precipitate was washed three times with distilled water at ambient temperature (the mass ratio of the solid phase to the liquid phase was 1 : 1) and then dried in a drier at $70^{\circ} \mathrm{C}$ for $1.5 \mathrm{~h}$. It was experimentally found that during the drying at temperatures $50-80^{\circ} \mathrm{C}$ within $5 \mathrm{~h}$ calcium sulphate hemihydrate did not dehydrate to anhydrite. The diagram showing the method in which the experiment was conducted is presented on Fig. 1. 


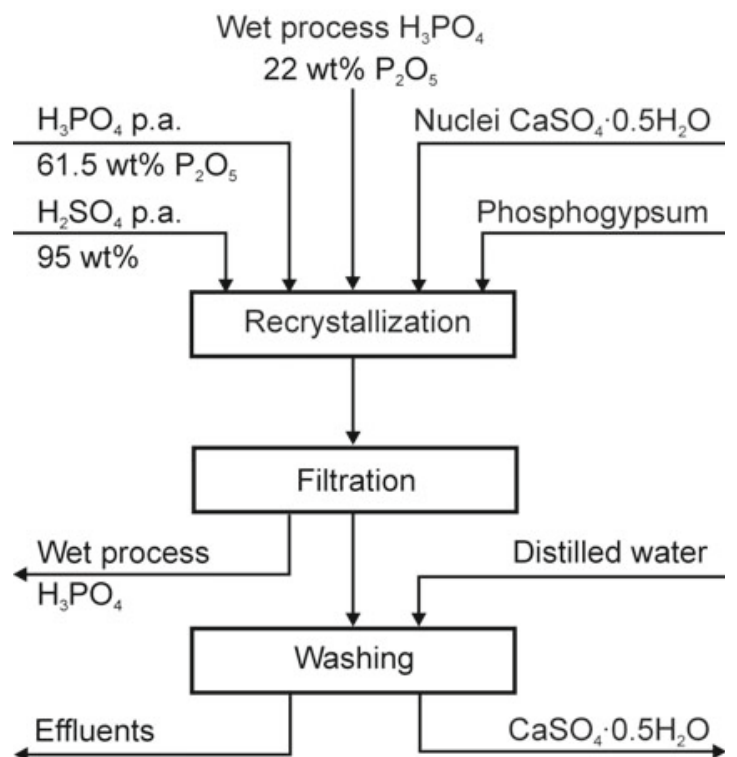

Figure 1. Diagram of the experimental method

\section{Sample characterization}

The X-ray diffraction analysis (X'Pert PRO Philips diffractometer with $\mathrm{CuK}_{\alpha}$ radiation) was used to determine the fraction of different forms of calcium sulphates and phase composition in the samples. The relative abundance of $\mathrm{CaSO}_{4} \cdot 2 \mathrm{H}_{2} \mathrm{O}, \alpha \mathrm{CaSO}_{4} \cdot 0.5 \mathrm{H}_{2} \mathrm{O}$ and $\mathrm{CaSO}_{4}$ phases were calculated from the (101) reflection of $\mathrm{CaSO}_{4} \cdot 2 \mathrm{H}_{2} \mathrm{O}$, the (121) reflection of $\alpha \mathrm{CaSO}_{4} \cdot 0.5 \mathrm{H}_{2} \mathrm{O}$ and the $(020)$ reflection of $\mathrm{CaSO}_{4}$. The fraction of $\mathrm{CaSO}_{4} \cdot 2 \mathrm{H}_{2} \mathrm{O}$, $\alpha \mathrm{CaSO}_{4} \cdot 0.5 \mathrm{H}_{2} \mathrm{O}, \mathrm{CaSO}_{4}$ in the samples and the degree of conversion of $\mathrm{CaSO}_{4} \cdot 2 \mathrm{H}_{2} \mathrm{O}$ to $\alpha \mathrm{CaSO}_{4} \cdot 0.5 \mathrm{H}_{2} \mathrm{O}$ and $\mathrm{CaSO}_{4}$ were determined from the following equations:

$F_{D H}=\frac{I_{D H} \cdot 100}{I_{D H}+I_{H H} \cdot k_{1}+I_{A H} \cdot k_{2}}$

$F_{H H}=\frac{I_{H H} \cdot k_{1} \cdot 100}{I_{D H}+I_{H H} \cdot k_{1}+I_{A H} \cdot k_{2}}$

$F_{A H}=\frac{I_{A H} \cdot k_{2} \cdot 100}{I_{D H}+I_{H H} \cdot k_{1}+I_{A H} \cdot k_{2}}$

$\alpha=\frac{\left(I_{H H} \cdot k_{1}+I_{A H} \cdot k_{2}\right) \cdot 100}{I_{D H}+I_{H H} \cdot k_{1}+I_{A H} \cdot k_{2}}$

where: $F_{D H}, F_{H H}$ and $F_{A H}$ are the fractions of $\mathrm{CaSO}_{4} \cdot 2 \mathrm{H}_{2} \mathrm{O}, \alpha \mathrm{CaSO}_{4} \cdot 0.5 \mathrm{H}_{2} \mathrm{O}$ and $\mathrm{CaSO}_{4}$ in the samples, $\alpha$ is the conversion degree of $\mathrm{CaSO}_{4} \cdot 2 \mathrm{H}_{2} \mathrm{O}, I_{D H}$, $I_{H H}$ and $I_{A H}$ are the peak intensities of $\mathrm{CaSO}_{4} \cdot 2 \mathrm{H}_{2} \mathrm{O}$ (121), $\alpha \mathrm{CaSO}_{4} \cdot 0.5 \mathrm{H}_{2} \mathrm{O}(110)$ and $\mathrm{CaSO}_{4}(020), k_{1}$ and $k_{2}$ are the coefficients (the ratio of peak intensity (110) $100 \mathrm{wt} \%$ of $\alpha \mathrm{CaSO}_{4} \cdot 0.5 \mathrm{H}_{2} \mathrm{O}$ to the peak intensity (121) $100 \mathrm{wt} \%$ of $\mathrm{CaSO}_{4} \cdot 2 \mathrm{H}_{2} \mathrm{O}$ and the ratio of peak intensity (020) $100 \mathrm{wt} \%$ of $\mathrm{CaSO}_{4}$ to the peak intensity (121) 100 wt $\%$ of $\left.\mathrm{CaSO}_{4} \cdot 2 \mathrm{H}_{2} \mathrm{O}\right)$.

The sulphate content in the wet process phosphoric acid was determined by a weight method according to PN-ISO 10084:2004 whereas the phosphates content by a spectrophotometric method according to PN-88/C-87015).

\section{RESULTS AND DISCUSSION}

\section{Study on transformation of $\mathrm{CaSO}_{4} \cdot 2 \mathrm{H}_{2} \mathrm{O}$ to $\alpha \mathrm{CaSO}_{4} \cdot \mathbf{0 . 5 \mathrm { H } _ { 2 } \mathrm { O }}$}

On the basis of the preliminary investigations it was found that the transformation of $\mathrm{CaSO}_{4} \cdot 2 \mathrm{H}_{2} \mathrm{O}$ to $\alpha \mathrm{CaSO}_{4} \cdot 0.5 \mathrm{H}_{2} \mathrm{O}$ should be carried out at temperature higher than $85^{\circ} \mathrm{C}$. This conclusion was based on the results of experiments, in which the $\mathrm{CaSO}_{4} \cdot 2 \mathrm{H}_{2} \mathrm{O}$ transformation proceeded in the phosphoric acid containing 21-30 wt \% $\mathrm{P}_{2} \mathrm{O}_{5}$ and 4-9 wt $\%$ sulphates, at temperature of $80^{\circ} \mathrm{C}$ and $85^{\circ} \mathrm{C}$ for $2 \mathrm{~h}$. Under these conditions, in only few cases, a small degree of conversion of $\mathrm{CaSO}_{4} \cdot 2 \mathrm{H}_{2} \mathrm{O}$ to $\alpha \mathrm{CaSO}_{4} \cdot 0.5 \mathrm{H}_{2} \mathrm{O}$ not higher than $28 \%$ was obtained in few experiments.

The transformation of calcium sulphate dihydrate at $90^{\circ} \mathrm{C}, 92^{\circ} \mathrm{C}$ and $95^{\circ} \mathrm{C}$ was carried out in the phosphoric acid containing 21-36 wt $\% \mathrm{P}_{2} \mathrm{O}_{5}$ and 4-9 wt \% sulphates for $2 \mathrm{~h}$. The X-ray diffraction analysis was used to determine the fraction of the particular phases present in the products and the degree of $\mathrm{CaSO}_{4} \cdot 2 \mathrm{H}_{2} \mathrm{O}$ dehydration was calculated. It is worthy to note that, in many experiments conducted the low degree of $\mathrm{CaSO}_{4} \cdot 2 \mathrm{H}_{2} \mathrm{O}$ transformation to anhydrite was obtained. The fraction of this phase in the conversion products in relation to the remaining phases amounted to maximum $9 \%$, and in the majority of cases this fraction was within the range $1-4 \%$. Therefore, the main phases in the products comprise either $\mathrm{CaSO}_{4} \cdot 2 \mathrm{H}_{2} \mathrm{O}$ or $\alpha \mathrm{CaSO}_{4} \cdot 0.5 \mathrm{H}_{2} \mathrm{O}$ or both simultaneously. The XRD pattern of one of the transformation products is shown in Figure 2.

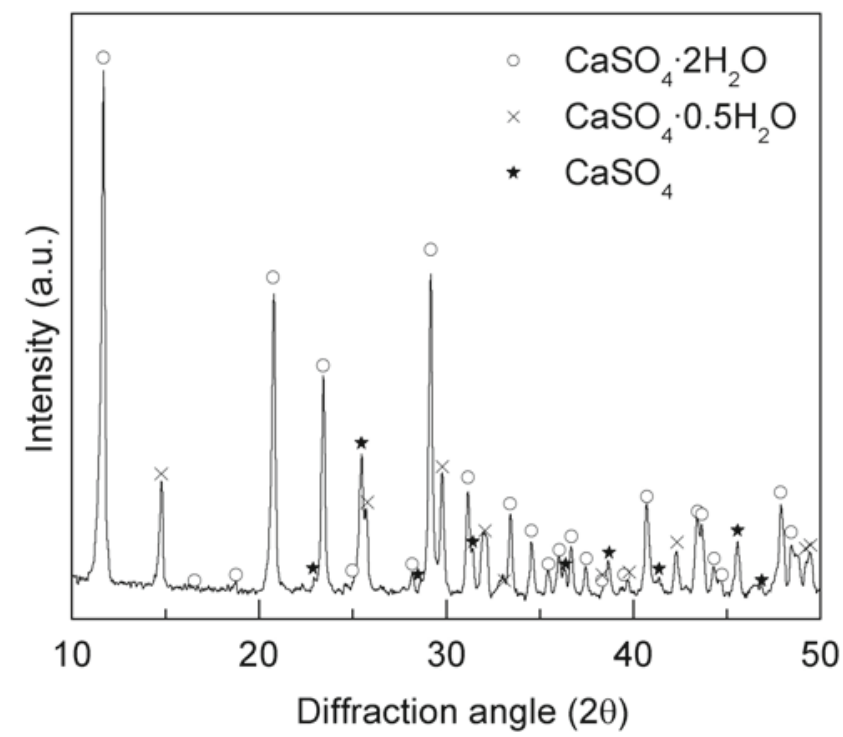

Figure 2. XRD pattern of transformation product $\mathrm{CaSO}_{4} \cdot 2 \mathrm{H}_{2} \mathrm{O}$ to $\alpha \mathrm{CaSO}_{4} \cdot 0.5 \mathrm{H}_{2} \mathrm{O}$

The relationships obtained, determining the influence of phosphates and sulphates in wet process phosphoric acid on the degree of $\mathrm{CaSO}_{4} \cdot 2 \mathrm{H}_{2} \mathrm{O}$ conversion were expressed mathematically by means of a nonlinear regression model with two independent variables in the form: $Y=b_{0}+b_{1} X_{1}+b_{2} X_{1}^{2}+b_{3} X_{2}+b_{4} X_{2}^{2}+b_{5} X_{1} X_{2}$ where: $X_{1}$ is the content of $\mathrm{P}_{2} \mathrm{O}_{5}$ in phosphoric acid (wt \%), $X_{2}$ is the content of sulphates in phosphoric acid (wt \%) and $Y$ is the degree of $\mathrm{CaSO}_{4} \cdot 2 \mathrm{H}_{2} \mathrm{O}$ conversion (\%). 
Table 2. Compilation of coefficients in the regression equations and their statistical estimation for particular conversion systems

\begin{tabular}{|c|c|c|c|c|c|c|c|c|c|c|c|}
\hline No. & Temp. & Nuclei & \multicolumn{9}{|c|}{ Polynomial equation coefficients } \\
\hline & ${ }^{\circ} \mathrm{C}$ & $w t \%$ & $b_{0}$ & $b_{1}$ & $b_{2}$ & $b_{3}$ & $b_{4}$ & $b_{5}$ & $R^{2}$ & $F$ & $F_{0.05}$ \\
\hline 1 & 90 & 0 & -3409.49 & 204.7054 & -2.5272 & 0 & 10.1826 & -4.3666 & 0.84 & 16.20 & 3.26 \\
\hline 2 & 92 & 0 & -515.05 & 0 & 0.5507 & 0 & 2.7946 & 0 & 0.81 & 19.32 & 4.26 \\
\hline 3 & 95 & 0 & 23.40 & 0 & -0.1536 & -65.6485 & 0 & 3.3590 & 0.78 & 30.76 & 2.98 \\
\hline 4 & 88 & 20 & -99.87 & 4.8581 & 0 & 0 & 0 & 0.4436 & 0.91 & 45.89 & 4.26 \\
\hline 5 & 90 & 20 & -899.50 & 60.2030 & -0.9771 & 71.9758 & -2.9089 & -1.4646 & 0.92 & 14.23 & 4.39 \\
\hline 6 & 92 & 20 & -556.04 & 34.8714 & -0.4625 & 79.3817 & -2.7631 & -2.0066 & 0.96 & 31.49 & 4.39 \\
\hline
\end{tabular}

The equation coefficients for particular series of experiments, calculated for independent variables and their statistical estimation where $R^{2}$ is the square of multiple correlation coefficients, $F$ is the calculated value of Snedecor's test for regression equation, and $F_{0.05}$ is the boundary value of $F$ test for significance level $\alpha=0.05$ are compiled in Table 2.

The regression relationship was estimated by the method of stepwise regression with entering of variables. The significance of multiple regression was validated using the $F$ Fisher-Snedecor test. The values of the coefficients of this function were determined using the Marquardt method and their significance was verified using the $t$-Student test.

The relationships described by regression equations are exemplified in Figs. $3 \mathrm{a}$ and $3 \mathrm{~b}$. It was found that the fraction of calcium sulphate hemihydrate in the precipitate increases in relation to the remaining phases with increasing the process temperature or the content of phosphates and/or sulphates in the liquid phase of the reaction mixture. The higher the process temperature, the higher degree of $\mathrm{CaSO}_{4} \cdot 2 \mathrm{H}_{2} \mathrm{O}$ crystallization was obtained in the phosphoric acid with a lower content of phosphates and/or sulphates.

For example: i) when the sulphate content in the initial phosphoric acid was $6 \mathrm{wt} \%$ then along with the increase in the phosphate concentration in the range of 28-35 wt $\% \mathrm{P}_{2} \mathrm{O}_{5}$, the fraction of $\alpha \mathrm{CaSO}_{4} \cdot 0.5 \mathrm{H}_{2} \mathrm{O}$ in the solid phase increased from $0 \%$ to $97.7 \%$ (at $90^{\circ} \mathrm{C}$ ), ii) when the sulphate content in the initial phosphoric acid amounted to $5 \mathrm{wt} \%$ then along with the increase of phosphate concentration 27-32 wt $\% \mathrm{P}_{2} \mathrm{O}_{5}$, the fraction of $\alpha \mathrm{CaSO} 4 \cdot 0.5 \mathrm{H}_{2} \mathrm{O}$ in the solid phase increased from $0 \%$ to $96.8 \%$ (at $92^{\circ} \mathrm{C}$ ), iii) when the phosphate content in the initial phosphoric acid was $26 \mathrm{wt} \% \mathrm{P}_{2} \mathrm{O}_{5}$ then along with sulphate increase by 4-7 wt $\%$ the fraction of $\mathrm{CaSO}_{4} \cdot 0.5 \mathrm{H}_{2} \mathrm{O}$ in the solid phase increased from $0 \%$ to $97.7 \%$ (at $95^{\circ} \mathrm{C}$ ).

On the basis of obtained results, the minimum content of $\mathrm{P}_{2} \mathrm{O}_{5}$ and $\mathrm{SO}_{4}{ }^{2-}$ in the phosphoric acid needed to achieve practically complete (96-98\%) conversion of $\mathrm{CaSO}_{4} \cdot 2 \mathrm{H}_{2} \mathrm{O}$ to $\alpha \mathrm{CaSO}_{4} \cdot 0.5 \mathrm{H}_{2} \mathrm{O}$ at 90,92 and $95^{\circ} \mathrm{C}$ was determined. The conversion isotherms were shown in the system: phosphate content/sulphate content in the phosphoric acid (Fig. 4). The regions over the plotted curves (and including the curves) are the regions, in which the conversion of calcium sulphate dihydrate to hemihydrate took place at a given temperature. The particular curves separate from each other the regions of metastable stability of $\mathrm{CaSO}_{4} \cdot 2 \mathrm{H}_{2} \mathrm{O}$ and $\alpha \mathrm{CaSO}_{4} \cdot 0.5 \mathrm{H}_{2} \mathrm{O}$. The total conversion under study proceeded over certain
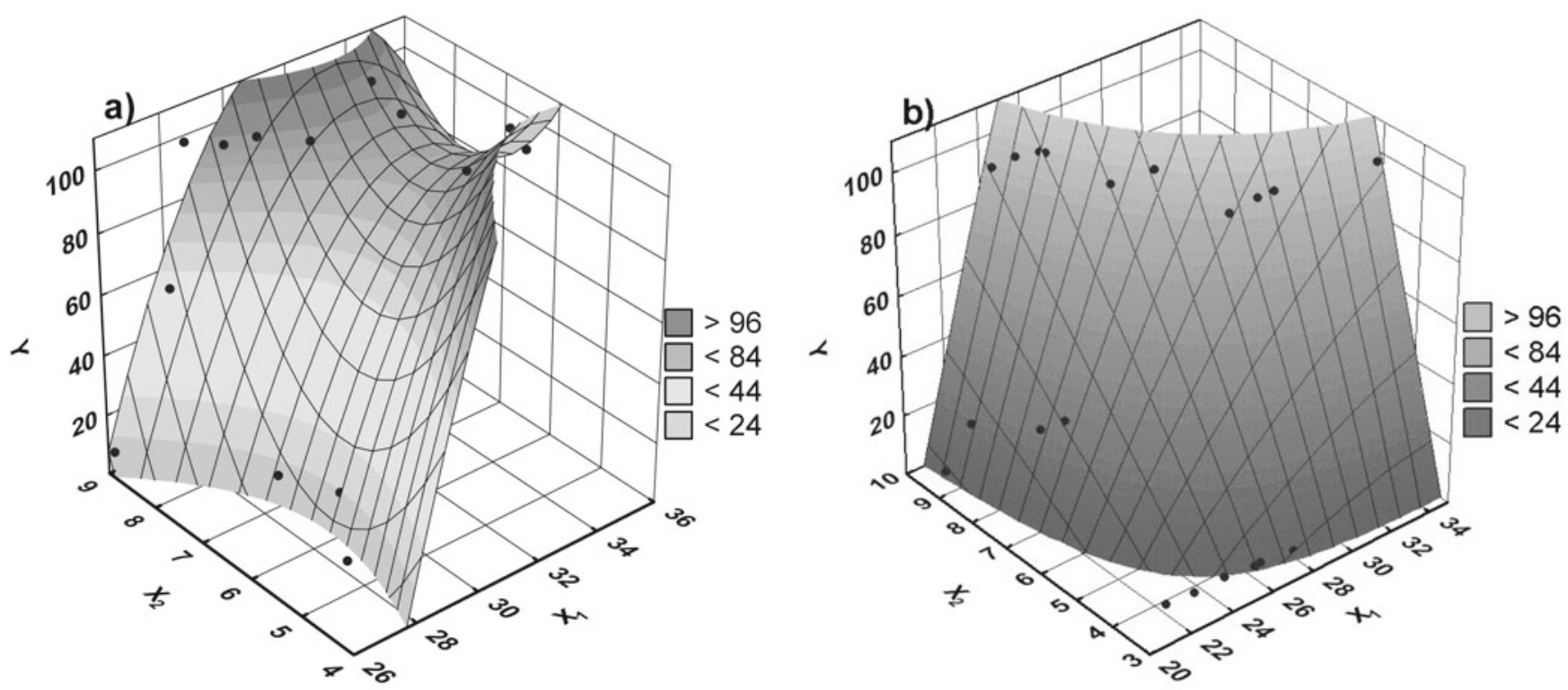

Figure 3. The influence of phosphates and sulphates on the degree of conversion of $\mathrm{CaSO}_{4} \cdot 2 \mathrm{H}_{2} \mathrm{O}$ to $\alpha \mathrm{CaSO}_{4} \cdot 0.5 \mathrm{H}_{2} \mathrm{O}$ and to $\mathrm{CaSO}$ : a) $90^{\circ} \mathrm{C}$ and b) $95^{\circ} \mathrm{C}$ 


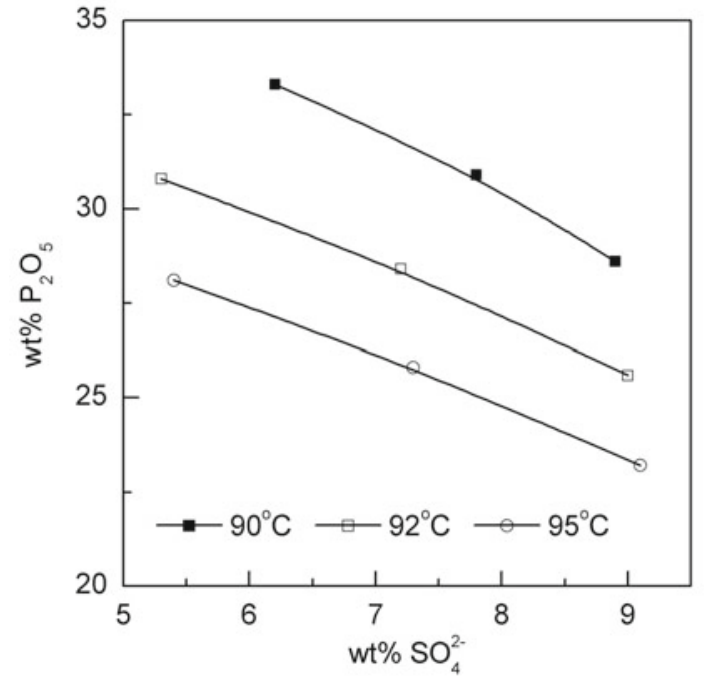

Figure 4. Conversion isotherms of $\mathrm{CaSO}_{4} \cdot 2 \mathrm{H}_{2} \mathrm{O}$ to $\alpha \mathrm{CaSO}_{4} \cdot 0.5 \mathrm{H}_{2} \mathrm{O}$ in the order: $\mathrm{P}_{2} \mathrm{O}_{5}$ content $/ \mathrm{SO}_{4}{ }^{2-}$ content in wet process phosphoric acid

isotherms under given process conditions (temperature, concentration of $\mathrm{P}_{2} \mathrm{O}_{5}$ and $\mathrm{SO}_{4}{ }^{2-}$ ), but not below them.

Therefore, a high concentration of phosphates and sulphates in the phosphoric acid, respectively, $29-31 \mathrm{wt} \%$ $\mathrm{P}_{2} \mathrm{O}_{5}$ and $8-9$ wt $\% \mathrm{SO}_{4}{ }^{2-}$ should be maintain in order to carry out the transformation process at temperature of $90^{\circ} \mathrm{C}$. By increasing the temperature to $95^{\circ} \mathrm{C}$ it is possible to decrease the content of both components down to 25-27 wt $\% \mathrm{P}_{2} \mathrm{O}_{5}$ and 6-7 wt $\% \mathrm{SO}_{4}^{2-}$. It was found that the acid viscosity increases with increasing the content of phosphate and sulphate in the phosphoric acid. The difficulties occurred in washing the precipitate and a considerable quantity of phosphates remained in insufficient washed calcium sulphate hydrate.

The transformation process of $\mathrm{CaSO}_{4} \cdot 2 \mathrm{H}_{2} \mathrm{O}$ should be carried out at the possibly lowest temperature and at a low content of sulphates in the phosphoric acid. This is associated with the influence of temperature and the reaction environment on the corrosion of equipment and installation as well as with the impact of sulphates on the crystal habit of calcium sulphate hydrates. Moreover, the wet process phosphoric acid with a high content of sulphates, for some applications, has to be subjected to desulphurization. In order to reduce these parameters, the influence of $\alpha \mathrm{CaSO}_{4} \cdot 0.5 \mathrm{H}_{2} \mathrm{O}$ crystallization nuclei addition on the $\mathrm{CaSO}_{4} \cdot 2 \mathrm{H}_{2} \mathrm{O}$ transformation was investigated.

Tests of transformation of $\mathrm{CaSO}_{4} \cdot 2 \mathrm{H}_{2} \mathrm{O}$ to $\alpha \mathrm{CaSO}$ ${ }_{4} \cdot 0.5 \mathrm{H}_{2} \mathrm{O}$ in the presence of calcium sulphate hemihydrate's crystallization nuclei

XRD analysis of transformation products of $\mathrm{CaSO}_{4} \cdot 2 \mathrm{H}_{2} \mathrm{O}\left(22 \mathrm{wt} \% \mathrm{P}_{2} \mathrm{O}_{5}\right.$ and $3.8 \mathrm{wt} \%$ of sulphates in the phosphoric acid, temperature $95^{\circ} \mathrm{C}$, time $2 \mathrm{~h}$ ) revealed a marked influence of $\alpha \mathrm{CaSO}_{4} \cdot 0.5 \mathrm{H}_{2} \mathrm{O}$ crystallization nuclei on the conversion when their fraction in the initial solid phase was $>10 \%$ (Fig. 5). On the basis of the obtained results it was decided that subsequent experiments will be carried out at the weight ratio of $\mathrm{CaSO}_{4} \cdot 2 \mathrm{H}_{2} \mathrm{O}$ to $\alpha \mathrm{CaSO}_{4} \cdot 0.5 \mathrm{H}_{2} \mathrm{O}$ crystallization nuclei in the initial solid phase equal to $4: 1$.

The transformation of calcium sulphate dihydrate was carried out at $88^{\circ} \mathrm{C}, 90^{\circ} \mathrm{C}$ and $92^{\circ} \mathrm{C}$ in the phosphoric

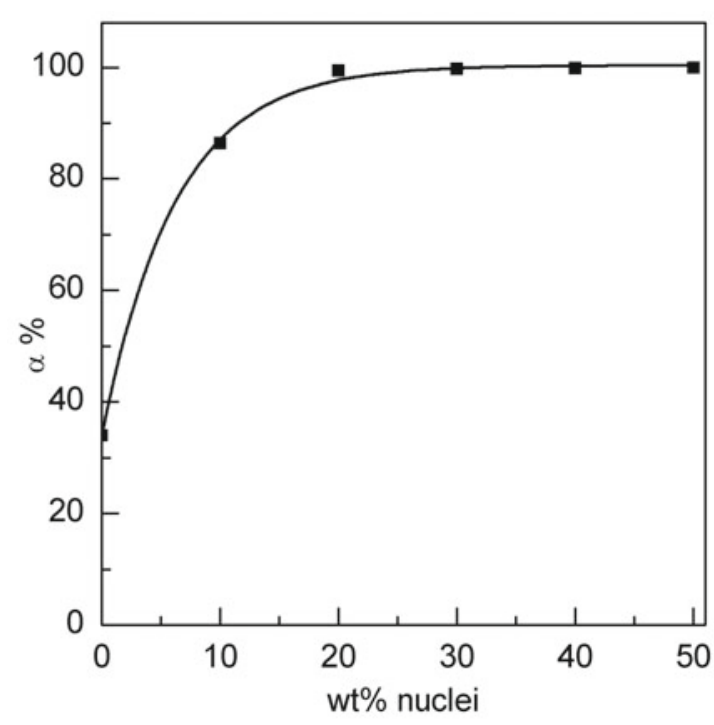

Figure 5. The influence of $\alpha \mathrm{CaSO}_{4} \cdot 0.5 \mathrm{H}_{2} \mathrm{O}$ crystallization nuclei on the degree of $\mathrm{CaSO}_{4} \cdot 2 \mathrm{H}_{2} \mathrm{O}$ to $\alpha \mathrm{CaSO}_{4} \cdot 0.5 \mathrm{H}_{2} \mathrm{O}$ conversion

acid containing 22-28 wt $\% \mathrm{P}_{2} \mathrm{O}_{5}$ and 2.2-6.1 wt $\%$ of sulphates for $1.5 \mathrm{~h}$. Therefore, the following parameters: the temperature, the process time and the content of sulphates in the initial phosphoric acid were lower in relation to those used in the experiments discussed in section Study on transformation of $\mathrm{CaSO}_{4} 2 \mathrm{H}_{2} \mathrm{O}$ to $\alpha \mathrm{CaSO}_{4} 0.5 \mathrm{H}_{2} \mathrm{O}$.

The obtained dependencies were expressed mathematically by means of a nonlinear regression model with two independent variables (Equation 5, Table 2). The appropriate relationships described by the regression equations are presented in Fig. 6.

In the experiments under study the transformation degree of $\mathrm{CaSO}_{4} \cdot 2 \mathrm{H}_{2} \mathrm{O}$ to anhydrite was higher than that described in section 3.1. The fraction of anhydrite in the products varied from $3 \%$ to $17 \%$, while in the majority of cases it amounted to $3-7 \%$. This could be caused by the presence of anhydrous calcium sulphate in $\alpha \mathrm{CaSO}_{4} \cdot 0.5 \mathrm{H}_{2} \mathrm{O}$ crystallization nuclei containing 3.5 wt $\% \mathrm{CaSO}_{4}$ which were added to the reactor.

It was found, similar to the previously discussed experiments, that with an increase of either the process temperature or the content of phosphates or sulphates in the liquid phase of the reaction mixture, the fraction of calcium sulphate hemihydrate in the precipitate was increasing in relation to the remaining phases. The higher the temperature of the process the higher degree of $\mathrm{CaSO}_{4} \cdot 2 \mathrm{H}_{2} \mathrm{O}$ transformation was achieved in the phosphoric acid with a lower content of phosphates and/or sulphates. However, it was observed that in the presence of transformation nuclei the dehydration of $\mathrm{CaSO}_{4} \cdot 2 \mathrm{H}_{2} \mathrm{O}$ to $\alpha \mathrm{CaSO}_{4} \cdot 0.5 \mathrm{H}_{2} \mathrm{O}$ proceeded with significant efficiency also at a lower temperature of $88^{\circ} \mathrm{C}$. It was found that by increasing the phosphate concentration in the liquid phase of the reaction mixture from about $22 \mathrm{wt} \% \mathrm{P}_{2} \mathrm{O}_{5}$ to $28 \mathrm{wt} \% \mathrm{P}_{2} \mathrm{O}_{5}$, in which the sulphate concentration was $3.7 \mathrm{wt} \%$, it is possible to obtain higher degrees of converting $\mathrm{CaSO}_{4} \cdot 2 \mathrm{H}_{2} \mathrm{O}$ to $\alpha \mathrm{CaSO}_{4} \cdot 0.5 \mathrm{H}_{2} \mathrm{O}$ increasing from $23 \%$ to about $85 \%$. At $90^{\circ} \mathrm{C}$, the degree of $\mathrm{CaSO}_{4} \cdot 2 \mathrm{H}_{2} \mathrm{O}$ transformation to $\alpha \mathrm{CaSO}_{4} \cdot 0.5 \mathrm{H}_{2} \mathrm{O}$ in the phosphoric acid containing $24 \mathrm{wt} \% \mathrm{P}_{2} \mathrm{O}_{5}$ increased from $81 \%$ to $97 \%$ along with the increase of the sulphates 

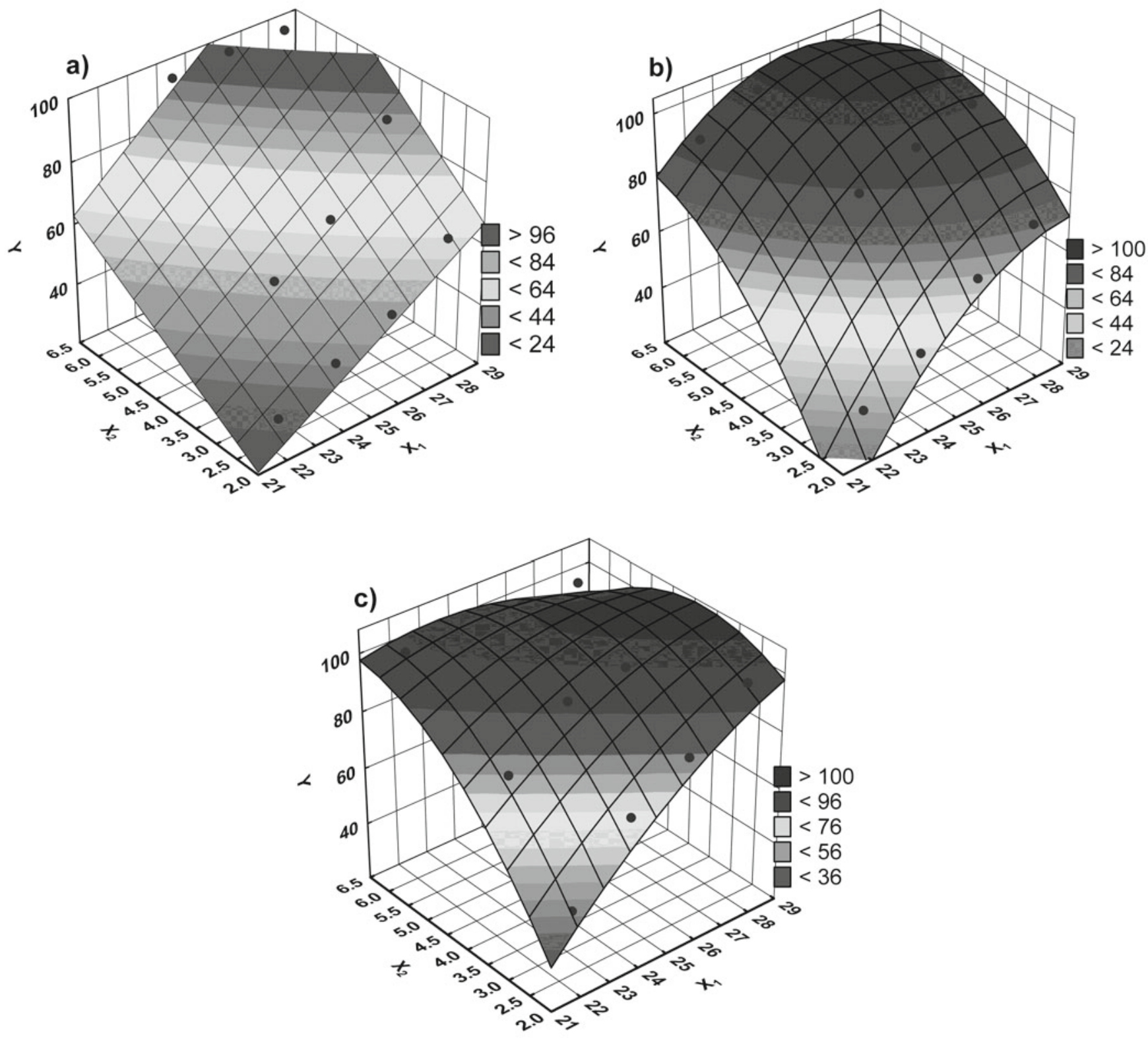

Figure 6. The influence of phosphates and sulphates on the degree of conversion of $\mathrm{CaSO}_{4} \cdot 2 \mathrm{H}_{2} \mathrm{O}$ to $\alpha \mathrm{CaSO}_{4} \cdot 0.5 \mathrm{H}_{2} \mathrm{O}$ and to $\mathrm{CaSO}$ in the presence of $\alpha \mathrm{CaSO}_{4} \cdot 0.5 \mathrm{H}_{2} \mathrm{O}$ crystallization nuclei: a) $88^{\circ} \mathrm{C}$, b) $90^{\circ} \mathrm{C}$ and c) $92^{\circ} \mathrm{C}$

content in this acid from $3.7 \mathrm{wt} \%$ to $6.1 \mathrm{wt} \%$. The fraction of $\alpha \mathrm{CaSO}_{4} \cdot 0.5 \mathrm{H}_{2} \mathrm{O}$ in the products obtained from $\mathrm{CaSO}_{4} \cdot 2 \mathrm{H}_{2} \mathrm{O}$ conversion in the phosphoric acid containing about $22 \mathrm{wt} \% \mathrm{P}_{2} \mathrm{O}_{5}$ and $3.7-6.1 \mathrm{wt} \%$ of sulphates, varied between approximately $72 \%$ and about $97 \%$, when the process temperature was the highest $\left(92^{\circ} \mathrm{C}\right)$. When the content of phosphates in the phosphoric acid solution was being raised from about $22 \mathrm{wt} \% \mathrm{P}_{2} \mathrm{O}_{5}$ to $28 \mathrm{wt} \%$ $\mathrm{P}_{2} \mathrm{O}_{5}$ (with the sulphates content of $2.2 \mathrm{wt} \%$ ) then the ratio of $\alpha \mathrm{CaSO}_{4} \cdot 0.5 \mathrm{H}_{2} \mathrm{O}$ in the products was increasing gradually, depending on temperature of the process, within the following ranges: $18-54 \%\left(88^{\circ} \mathrm{C}\right), 21-66 \%$ $\left(90^{\circ} \mathrm{C}\right)$ and $42-96 \%\left(92^{\circ} \mathrm{C}\right)$.

The minimum contents of $\mathrm{P}_{2} \mathrm{O}_{5}$ and $\mathrm{SO}_{4}{ }^{2-}$ in the phosphoric acid which is necessary to obtain a high transformation of $\mathrm{CaSO}_{4} \cdot 2 \mathrm{H}_{2} \mathrm{O}$ to $\alpha \mathrm{CaSO}_{4} \cdot 0.5 \mathrm{H}_{2} \mathrm{O}(>85 \%)$ at 82,90 and $92^{\circ} \mathrm{C}$ at the presence of $\alpha \mathrm{CaSO}_{4} \cdot 0.5 \mathrm{H}_{2} \mathrm{O}$ crystallization nuclei were determined. Similarly, as previously, the conversion isotherms were plotted in the system: phosphate content/sulphate content in phosphoric acid (Fig. 7).

It was found that the content of sulphates and phosphates in the phosphoric acid required for the appropriate course of the conversion of $\mathrm{CaSO}_{4} \cdot 2 \mathrm{H}_{2} \mathrm{O}$ to $\alpha \mathrm{CaSO}_{4} \cdot 0.5 \mathrm{H}_{2} \mathrm{O}$ can be efficiently reduced by the introduction of nuclei of calcium sulphate hemihydrate into the transformation reactor. Therefore, when the process is carried out in the phosphoric acid containing approximately $6 \mathrm{wt} \%$ sulphates and $>24 \mathrm{wt} \% \mathrm{P}_{2} \mathrm{O}_{5}$, in the presence of nuclei in the amount of $20 \%$ (in relation to phosphogypsum) it is possible to lower the conversion temperature by $7^{\circ} \mathrm{C}$ (from 95 to $88^{\circ} \mathrm{C}$ ).

\section{CONCLUSIONS}

While observing the influence of temperature and the content of phosphates and sulphates in the wet process phosphoric acid on the transformation of $\mathrm{CaSO}_{4} \cdot 2 \mathrm{H}_{2} \mathrm{O}$ to $\alpha \mathrm{CaSO}_{4} \cdot 0.5 \mathrm{H}_{2} \mathrm{O}$, it was found that: 


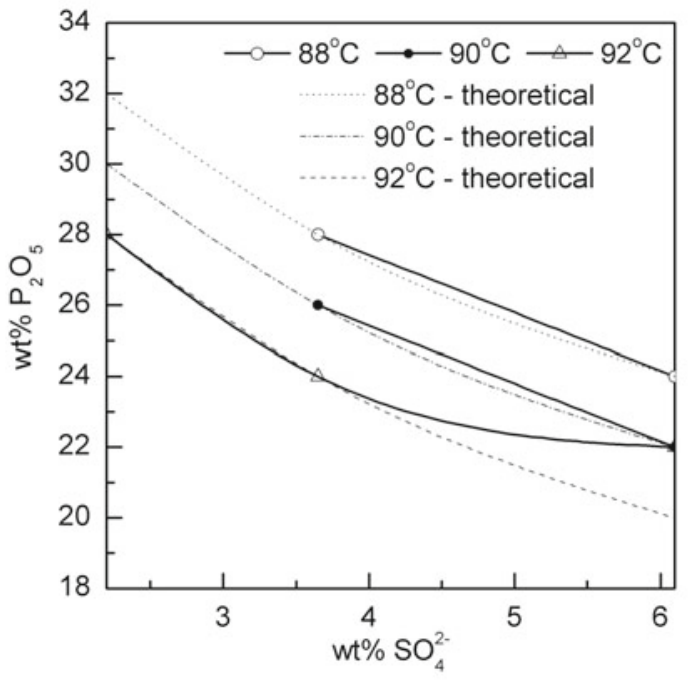

Figure 7. Conversion isotherms of $\mathrm{CaSO}_{4} \cdot 2 \mathrm{H}_{2} \mathrm{O}$ to $\alpha \mathrm{CaSO}_{4} \cdot 0.5 \mathrm{H}_{2} \mathrm{O}$ in the presence of $\alpha \mathrm{CaSO}_{4} \cdot 0.5 \mathrm{H}_{2} \mathrm{O}$ crystallization nuclei in the order: $\mathrm{P}_{2} \mathrm{O}_{5}$ content/ $\mathrm{SO}_{4}{ }^{2-}$ content in wet process phosphoric acid

1. an increase of the process temperature and/or the content of $\mathrm{SO}_{4}{ }^{2-}$ and/or $\mathrm{PO}_{4}{ }^{3-}$ in the phosphoric acid affected the increase of the degree of transformation of $\mathrm{CaSO}_{4} \cdot 2 \mathrm{H}_{2} \mathrm{O}$ to $\alpha \mathrm{CaSO}_{4} \cdot 0.5 \mathrm{H}_{2} \mathrm{O}$,

2. a higher reaction temperature enables to carry out the conversion under milder conditions in relation to the content of $\mathrm{SO}_{4}{ }^{2-}$ and $\mathrm{PO}_{4}{ }^{3-}$ in the phosphoric acid,

3. the addition of $\alpha \mathrm{CaSO}_{4} \cdot 0.5 \mathrm{H}_{2} \mathrm{O}$ crystallization nuclei enabled the achievement of a high degree of $\mathrm{CaSO}_{4} \cdot 2 \mathrm{H}_{2} \mathrm{O}$ conversion to $\alpha \mathrm{CaSO}_{4} \cdot 0.5 \mathrm{H}_{2} \mathrm{O}$ at lower process temperatures and at a lower content of phosphates and sulphates in $\mathrm{H}_{3} \mathrm{PO}_{4}$.

It was found that the transformation of $\mathrm{CaSO}_{4} \cdot 2 \mathrm{H}_{2} \mathrm{O}$ to $\alpha \mathrm{CaSO}_{4} \cdot 0.5 \mathrm{H}_{2} \mathrm{O}$ should be carried out in the presence of $\alpha \mathrm{CaSO}_{4} \cdot 0.5 \mathrm{H}_{2} \mathrm{O}$ crystallization nuclei addition (in the amount of $20 \%$ in relation to $\mathrm{CaSO}_{4} \cdot 2 \mathrm{H}_{2} \mathrm{O}$ ), at a temperature of $90 \pm 2^{\circ} \mathrm{C}$, and at the content of sulphates $4 \pm 1 \mathrm{wt} \%$ and phosphates $27 \pm 1 \mathrm{wt} \% \mathrm{P}_{2} \mathrm{O}_{5}$ in the wet process phosphoric acid. By maintaining such conditions of the process it is possible to achieve a high degree of $\mathrm{CaSO}_{4} \cdot 2 \mathrm{H}_{2} \mathrm{O}$ dehydration to $\alpha \mathrm{CaSO}_{4} \cdot 0.5 \mathrm{H}_{2} \mathrm{O}$.

The final effect of our investigations will be the proposal for modernization of DH-process in the direction: enhancement of the degree of phosphates conversion from phosphate rock to the wet process phosphoric acid (an improvement of phosphate efficiency of the process), production of phosphoric acid with higher concentration, substantial improvement in purity of waste calcium sulphate hydrate and lowering its quantity. The indirect effect will be the prolongation of landfill exploitation period, the limitation of phosphoric raw materials consumption per 1 ton of $\mathrm{P}_{2} \mathrm{O}_{5}$ in the phosphoric acid, which will results in lower impact of wet process phosphoric acid production on the environment.

\section{ACKNOWLEDGEMENTS}

This scientific work was funded from financial support on science as research project for 2010-2013.

\section{LITERATURE CITED}

1. Heffer, P. \& Prud'homme, M. (2009). Summary Report 'Medium-Term Outlook for Global Fertilizer Demand, Supply and Trade: 2009-2013, Part 1- Global Economic Context and Agricultural Situation, 77th IFA Annual Conference, Shanghai, May 1-10.

2. Heffer, P. \& Prud'homme, M. (2008). Outlook for World Fertilizer Demand, Supply, and Supply/Demand Balance. Turk J. Agric. For. 32(3), 159-164. TAR-0803-38.

3. Schlag, S. (2010). Wet-Process Phosphoric Acid, CEHReport.

4. Becker, P. (1989.) Phosphates and phosphoric acid (second ed.). Marcel Dekker, Inc., New York.

5. Integrated Pollution Prevention and Control Reference Document on Best Available Techniques for the Manufacture of Large Volume Inorganic Chemicals - Ammonia, Acids and Fertilisers, European IPPC Bureau, Seville, August 2007, from http://eippcb.jrc.es/

6. Papadopoulosa, A.I. \& Seferlis, P. (2009). Generic modelling, design and optimization of industrial phosphoric acid production processes. Chem. Eng. Process. 48(1), 493-506. DOI: 10.1016/j.cep.2008.06.011.

7. Abu-Eishah, S.I. \& Abu-Jabal, N.M. (2001). Parametric study on the production of phosphoric acid by the dihydrate process. Chem. Eng. J. 81(1-3), 231-250. DOI: 10.1016/S13858947(00)00166-2.

8. Agarwal, S.S. \& Murugaperumal, S. (1998). HDH process technology for phosphoric acid production. Phosph. Potass. 214, 38-42.

9. Singh, N.B. \& Middendorf, B. (2007). Calcium sulphate hemihydrate hydration leading to gypsum crystalization. Prog. Cryst. Growth Charact. Mater. 53(1), 57-77. DOI: 10.1016/j. pcrysgrow.2007.01.002.

10. El Moussaouiti, M. Boistelle, R. Bouhaouss, A. \& Klein, J.P. (1997). Crystalization of calcium sulphate hemihydrate in concentrated phosphoric acid solutions. Chem. Eng. J. 68(2-3), 123-130. DOI: 10.1016/S1385-8947(97)00116-2.

11. Prayon displays its phosphate technology and operations. (1991). Phosph. Potass. 174, 38-42.

12. Mitsui Toatsu Chemicals'MT-50 Hemihydrate-Dihydrate Phosphoric Acid Process. (1988). Phosph. Potass. 157, 29-31.

13. Phosphoric acid technology at large. (1999). Phosph. Potass. 221, 55-59.

14. Phosphoric acid technology at large -Part II. (1999). Phosph. Potass. 224, 19-25.

15. Dorozhkin, S.V. (1997). Fundamentals of Wet-Process phosphoric Acid production. 2. Kinetics and Mechanism of $\mathrm{CaSO}_{4} \cdot 0.5 \mathrm{H}_{2} \mathrm{O}$ Surface Crystallization and Coating Formation. Ind. Eng. Chem. Res. 36(2), 467-473. DOI: 10.1021/ie960219f.

16. Xibing Li, Zilong Zhou, Guoyan Zhao, \& Zhixiang Liu. (2008). Utilization of phosphogypsum for backfilling, way to relieve its environmental impact. Gospodarka Surowcami Mineralnymi, 24(4/3), 226-232.

17. Altun, I.A. \& Sert, Y. (2004). Utilization of weathered phosphogypsum as set retarder in Portland cement. Cem. Concr. Res. 34(4), 677-680. DOI: 10.1016/j.cemconres.2003.10.017.

18. Weiguo Shen, Mingkai Zhhou, \& Qinglin Zhao. (2007). Study on lime-fly ash-phosphogypsum binder. Constr. Buil. Mater. 21(7), 1480-1485. DOI: 10.1016/j.conbuildmat.2006.07.010.

19. Rusch, K.A. Guo, T. \& Seals, R.K. (2002). Stabilization of phosphogypsum using class $\mathrm{C}$ fly ash and lime: assessment of the potential for marine applications. J. Hazard. Mater. 93(2), 167-186. DOI: 10.1016/S0304-3894(02)00009-2.

20. Dang, L. Wie, H. Zhu, Z. \& Wang, J. (2007). The influence of impurities on phosphoric acid hemihydrate crystallization. J. Cryst. Growth, 307(1), 104-111. DOI: 10.1016/j. jcrysgro.2007.05.041.

21. Thyes, T. (2003). Influence of the rock impurities on the phosphoric avid process, products and some downstream uses, 
IFA Technical Committee Meeting, Abu Dabi, October 2003.

22. Hamdona, S.K. \& Al Hadad, U.A. (2007). Crystallization of calcium sulphate dihydrate in the presence of some metal ions, J. Cryst. Growth, 299(1), 146-151. DOI: 10.1016/j. jcrysgro.2006.11.139.

23. Rashad, M.M. Mahmoud, M.H.H. Ibrahim, I.A. \& Abdel-Aal, E.A. (2004). Crystallization of calcium sulphate dihydrate under simulated conditions of phosphoric acid production in the presence of aluminum and magnesium ions. J. Cryst. Growth, 267(1-2), 372-379. DOI: 10.1016/j.jcrysgro.2004.03.060. 